\title{
Contamination of Drinking Water by Arsenic in South-East Asia: Causes, Effects and Remediation
}

\author{
M. Aminur Rahman \\ Laboratory of Marine Biotechnology, Institute of Bioscience, Universiti Putra Malaysia, 43400 UPM Serdang, \\ Selangor, Malaysia (Email: aminur1963@gmail.com)
}

\begin{abstract}
Groundwater contamination by arsenic in different parts of the world is an outcome of natural and/or anthropogenic sources, leading to adverse effects on human health and ecosystem. Millions of people from different countries are heavily dependent on groundwater, which contains higher level of arsenic. Commonly, groundwater is an only source of water in the South-East Asian countries for drinking and domestic purposes. However, the presence of raised concentrations of inorganic arsenic in groundwater in South-East Asian countries, particularly in the regions of Bangladesh and the eastern part of India, is a cause for concern. Most people residing in this geographic location have no alternative but to drink contaminated groundwater, which has arsenic concentrations above the permissible limit $(0.01 \mathrm{mg} / \mathrm{L})$. As a result, approximately 123 million people in Bangladesh and India face higher risk of cancer, as well as risk of cardiovascular and neurologic diseases. Many techniques for removing arsenic from drinking water are accessible. This paper has mainly been focused on the region of South-East Asian countries, especially Bangladesh and India to investigate the extent of arsenic contamination and its toxic effects on human health, explore the sources of arsenic in this region, and compare and contrast the technologies of arsenic removal from drinking water in general.
\end{abstract}

Keywords - Groundwater, arsenic contamination, causes, health hazards, remediation.

\section{ARSENIC CONTAMINATION: CAUSES, INCIDENCES AND CONSEQUENCES}

A metallic element that forms a number of poisonous compounds, arsenic is found in nature at low levels mostly in compounds with oxygen, chlorine, and sulphur. These are called inorganic arsenic compounds. Arsenic is present in the environment and humans all over the world, and is exposed to small amounts, mostly through food, water, and air. Contamination of groundwater, either from anthropogenic or natural sources with several social impacts, has now turned to be a major environmental concern in different parts of the world. Millions of people in several countries are exposed to high levels of arsenic via intake of arsenic-rich groundwater. Elevated level of arsenic in groundwater has been well documented in Chile, Mexico, China, Argentina, USA, and Hungary $[1,2]$ as well as in the Indian State of West Bengal, Bangladesh, and Vietnam [2-6]. About 150 million people around the world are estimated to be affected globally with an increasing prospect as new affected areas are continuously discovered [7]. Ground water contamination is almost continuously the after effect of human activities. In zones, where population density is high and human utilization of the land is concentrated, ground water is particularly vulnerable. Virtually any activity whereby chemicals or wastes may be released to the environment, either intentionally or accidentally, has the potential to pollute ground water. (EPA/625/R - 93/002). At the point, when ground water becomes to be distinctly polluted, it is difficult, especially for the rural households, supplied with scattered hand-pump tubewells. Thereafter, it has become a major public health problem throughout South-East Asia, particularly more severe at the high-dense population areas around the greater Dhaka, Chittagong and Khulna regions of Bangladesh, and therefore, is a great burden on water supply authorities. In developing countries like India and Bangladesh, the high prevalence of contamination, the isolation and poverty of the rural population, and the high cost and complexity of arsenic removal systems have imposed a programmatic and policy challenge on an unprecedented scale $[8,9]$.

Bangladesh is situated mainly in a river delta, and this gives ample opportunity for the exploitation of surface water in most parts of the country. However, the river water available is often very turbid, polluted, and salty in coastal areas; and it fluctuates significantly in level and quality between the monsoon and dry seasons. The groundwater table has, in practice, been the major source of drinking water. It offers great opportunities for sinking shallow wells and deep wells in most areas, and these have gradually been availed of by most of the population, with help from both public and private sector providers. There are now around 7.0 million tubewells (hand pump tubewells, deep set tubewells, and deep tubewells) in the country, 5.5 million of which are constructed by the private sector for private owners, the rest by the Government ( 1.2 million) or by NGOs ( 0.3 million). The average number of people served by a tubewell is 20 (DPHE). The tubewells have ensured basic levels of drinking water supply to most of the population, and this could be called a success of sorts, although the poor often still have no access close to their homes [10]. Unfortunately, although $80 \%$ of the populations have access to some formof improved water supply (a figure sometimes questioned because of conflicting surveys), arsenic contamination of wells has complicated the situation by 
causing considerable health problems. Between $16 \%$ and $25 \%$ of all existing wells in Bangladesh are contaminated by arsenic, some seriously. A recent study undertaken as part of the preparation for the Government's 2005 Sector Development Program (SDP) suggests that the present bacteriologically and chemically safe coverage may even be as low as $59 \%$. Moreover, more than $25 \%$ of the people are using unsafe tubewells, leading to the recognition that other water quality issues require immediate attention [11].

Groundwater arsenic contamination in Bangladesh is reported to be the biggest arsenic calamity in the world in respects of the affected population [12]. It was first detected around Bangladesh in 1993 [13]. The Government of Bangladesh has addressed it as a national disaster. Further investigations were carried out in the following years. The institutions that contributed in the investigations are the School of Environmental Studies (SOES) from Jadavpur University in Calcutta, Bangladesh Atomic Energy Commission (BAEC), Dhaka Community Hos pital(DCH), Department of Public Health Engineering (DPHE), and National Institute of Preventive and Social Medicine (NIPSOM) [14]. DPHE collected and analysed 31,651 well water samples with the as sistance of WHO, UNICEF and DFID [15]. The laboratory reports have confirmed that the groundwater in Bangladesh is severely contaminated by arsenic. In consequence, a large number of populations in Bangladesh are suffering from the toxic effects of arsenic contaminated water.

Recent studies in Bangladesh indicate that the groundwater is severely contaminated with arsenic above the maximum permissible limit of drinking water. In 1996, altogether 400 measurements were conducted in Bangladesh [16]. Arsenic concentrations in about half of the measurements were above the maximum permissible level of $0.05 \mathrm{mg} / \mathrm{l}$ in Bangladesh. In 1998, British Geological Survey (BGS) collected 2022 water samples from 41 arsenic-affected areas including the major districts of over-populated Dhaka and Chittagong divisions [14, 16]. Laboratory tests revealed that $35 \%$ of these water samples were found to have arsenic concentrations above the level of $0.05 \mathrm{mg} / 1$ [14].

\section{ARSENIC CONTAMINATION: SOCIAL AND HEALTH HAZARDS}

Arsenic, a well-known carcinogen, is considered as one of the world's most hazardous chemicals [17]. Excessive and long-term (such as 5-10years) human intake of toxic inorganic arsenic from drinking water and food may result in arsenicosis, a common name generally used for arsenic-related health problems including skin disorders, skin cancers, internal cancers (bladder, kidney, and lung), diseases of the blood vessels of the legs and feet, possibly diabetes, increased blood pressure, and reproductive disorders [18-20]. In terrestrial environment, the inorganic forms of arsenic (such as trivalent arsenite (As III) and pentavalent arsenate ( $\mathrm{AsV}$ ) are more prevalent and toxic than the organic forms in general. Arsenic exerts detrimental effects on general protein metabolism with high toxicity by reacting with sulfhydryl groups existing in the cysteine residues [21].

Arsenicosis causes dire consequences for the livelihood, family life, and earning capability when individuals fall victim. At larger perspectives elevated arsenic contamination of a region may result in societal stress, disability in individuals, poverty, and decreased market value of potentially contaminated agricultural products leading to low income to the affected farmers [22]. Absence of taste, odour, colour, and exposure make arsenic impossible for a layman to detect and avoid. Applying the WHO provisional guideline for drinking water of $10-50 \mathrm{ppb}$ of arsenic, a population of more than 100 million people worldwide is at risk, and of these more than 45 million people mainly in developing countries from Asia are at risk of being exposed to more than $50 \mathrm{ppb}$ of arsenic, which is the maximum concentration limit in drinking water in most of the countries in Asia [7].

\section{ARSENIC CONTAMINATION: ASSESSMENT OF REMEDIATION TECHNIQUES}

The most common using arsenic removal technologies in Bangladesh (including other South-East-Asian countries) can be grouped into the following categories:

\section{A. Oxidation and sedimentation}

In situ oxidation of arsenic and iron in the aquifer has been tried, for example, in Bangladesh under the Arsenic Mitigation Pilot Project of the Department of Public Health Engineering (DPHE) and the Danish Agency for International Development (DANIDA). The aerated tubewell water is stored in feed water tanks and released back into the aquifers through the tubewell by opening a valve in a pipe connecting the water tank to the tubewell pipe under the pump head. Chlorine and potassium permanganate are used for oxidation of Arsenic (AsIII) to Arsenic $(\mathrm{AsV})$ in many treatment processes in Bangladesh. SORAS (solar oxidation and removal of arsenic) is a simple method of solar oxidation of arsenic in transparent bottles to reduce arsenic content of drinking water [23]. Ultraviolet radiation can catalyse the process of oxidation of arsenite in the presence of other oxidants such as oxygen [24]. Experiments in Bangladesh show that the process on average can reduce the arsenic content of water to about one-third of the original concentration [8]. Arsenic reduction by plain sedimentation appears to be dependent on water quality and in particular the presence of alkalinity and precipitating iron in water. Passive sedimentation, in most cases, failed to reduce arsenic to the desired level of $50 \mu \mathrm{g} / \mathrm{L}$ in a rapid assessment of technologies conducted in Bangladesh [25].

\section{B. Coagulation and filtration}

In the process of coagulation and flocculation, arsenic is removed from solution through three mechanisms:

a. Precipitation: The formation of insoluble compounds

b. Coprecipitation: The incorporation of soluble arsenic species into a growing metal hydroxide phase 
c. Ads orption: The electros tatic binding of soluble arsenic to external surfaces of the insoluble metal hydroxide [26].

Precipitation, coprecipitation, and adsorption by coagulation with metal salts and lime followed by filtration is a well-documented method of arsenic removal from water.

The technologies developed based on the coagulation-sedimentation-filtration process include:

- Bucket treatment unit [27]

- Stevens Institute technology [28]

- Fill and draw treatment unit [28]

- Tubewell-attached arsenic treatment unit [29]

- Iron-ars enic treatment unit [30]

The bucket treatment unit, developed by the DPHE-DANIDA Project and improved by the Bangladesh University of Engineering and Technology (BUET), is based on coagulation, coprecipitation, and adsorption processes.

\section{Sorptive filtration}

Several sorptive media have been reported to remove arsenic from water. As with the coagulation process, prechlorination improves the column capacity dramatically. The activated alumina-based sorptive media used in Bangladesh include:

- BUET activated alumina

- Alcan enhanced activated alumina

- Apyron arsenic treatment unit

The BUET iron-coated sand filter was constructed and tested on an experimental basis and found to be very effective in removing arsenic from groundwater. The unit needs pretreatment for the removal of excess iron to avoid clogging of the active filter bed. Iron-coated sand is prepared following a procedure similar to that adopted by Joshi and [31]. The Shapla arsenic filter, a household-level arsenic removal unit, has been developed and is being promoted by International Development Enterprises (IDE), Bangladesh [28].

The READ-F arsenic filter is promoted by Shin Nihon Salt Co. Ltd., Japan, and Brota Services International, Bangladesh, for arsenic removal in Bangladesh. READ-F displays high selectivity for arsenic ions under a broad range of conditions and effectively adsorbs both arsenite and arsenate. The READ-F is ethylene-vinyl alcohol copolymer-borne hydrous cerium oxide in which hydrous cerium oxide $(\mathrm{CeO} 2 . \mathrm{nH} 2 \mathrm{O})$ is the adsorbent. Laboratory tests at the BUET and field testing of the materials at several sites under the supervision of the BAMWSP showed that the adsorbent is highly efficient in removing arsenic from groundwater [32]. One household treatment unit and one community treatment unit based on the READ-F adsorbent are being promoted in Bangladesh [28]. The units need iron removalby sand filtration to avoid clogging of the resin bed by iron flocs. Hence, the development of ion-specific resin for exclusive removal of arsenic can make the process very attractive. Also, the well-known American company (Tetrahedron, Inc.) promoted ion exchange-based arsenic removal technology, which has been reported to be partly used in Bangladesh [28].
A considerable portion of external investment in Dhaka and Chittagong areas has gone into urban water supply and has remained outside the context of Integrated Urban Development Projects (IUDPs). Asian Development Bank (ADB) and the World Bank have supported projects dedicated to urban water supply in Bangladesh. In 2007, the Japanese Government approved a loan of SDR100 million for the Karnaphuli Water Supply Project in Chittagong. Department for International Development's (DFID) main activities in urban water supply are part of the $£ 17$ million Advancing Sustainable Health Project [33], which has both rural and urban water supply components, the latter notably in the slums of Dhaka and Chittagong. WaterAid is the management contractor supervising the implementation of this program through some $20 \mathrm{NGOs,} \mathrm{and}$ outside the context of government implementation processes. The evaluation mission had occasion to visit one slum in Dhaka and noted that the NGOs involved had been highly active and had achieved some good results. DFID is also funding urban water supply activities through the Urban Partnerships for Poverty Reduction (UPPR) Project [34], approved in 2007 and implemented by UNDP.

Water supply in rural areas or countryside is almost completely based on hand pumps and deep well extraction. ADB has not been active in rural water supply, unlike the World Bank and DFID. The World Bank operates through DPHEand to some extent through the Social Development Foundation. DPHE has attempted to promote private sector participation in rural water supply but has so far not been successful. The Social Development Foundation was more successful, but the scale is very small: some six pilot schemes were able to attract cofinancing from private investors. An earlier project specializing in the mitigation of arsenic contamination was more successful, especially in the screening and marking of contaminated wells [35]. Arsenic and bacteriological contamination have, however, remained a persistent problem in many areas. This may have lowered the coverage of safe drinking water supply in rural areas by about $20 \%$, although water availability per se is not a serious problem, except for the poorest.

\section{CONCLUSION}

Groundwater arsenic contamination is an distressing problem on a global measure. In the present investigation, we tried to elaborate on different natural and anthropogenic sources of arsenic in groundwater. We have also reviewed problem of arsenic contamination in groundwater in different parts of the world, particularly in South-East-Asian countries followed by detailed outlook in epidemiology and toxicity mechanisms of arsenic in animals and human beings. To combat arsenic problems, various remediation methods have been critically evaluated. Majority of the existing technologies for removal of arsenic involve the direct removal of As V or converting As III to As V followed by removal of AsV. Governmental and donor financial and logistic assistance may be essential to reduce arsenicosis. Besides, extensive research should address the understanding of the occurrence, origin, and dis tribution pattern of arsenic. The government should monitor industrial and 
agricultural activities leading to arsenic pollution. More technical assistance should be rendered to mining or chemical plants to deal with sewage and sludge storage and waste treatment. Research departments should increase the frequency of sampling and analys is of the discharge from industrial plants. This paper reflects the latest state of the art on understanding of various interdisciplinary facets of the problem of arsenic in environmental realm, mechanisms of mobilization in groundwater, biogeochemical interactions, and the mitigation techniques for maintaining the best of human health and environment.

\section{REFERENCES}

[1] Smedley, P.L. and Kinniburgh, D.G. 2002. A review of the source, behaviour and distribution of arsenic in natural waters. Applied Geochemistry, 17(5): 517-568. https://doi.org/10.1016/S0883-2927(02)00018-5

[2] Bhattacharya, P., Jacks, G., Ahmed, K.M., Routh, J. and Khan, A.A. 2002. Arsenic in groundwater of the Bengal Delta Plain aquifers in Bangladesh. Bulletin of Environmental Contamination and Toxicology, 69(4): 538-545. https://doi.org/10.1007/s00128-002-0095-5

[3] Bhattacharya, P. Chatterjee, D. and Jacks G. 1997. Occurrence of arsenic-contaminated groundwater in alluvial aquifers from delta plains, eastern India: options for safe drinking water supply. International Journal of Water Resources Development, 13(1): 79-92 https://doi.org/10.1080/07900629749944

[4] Bhattacharya, P., Welch, A.H., Stollenwerk, K.G., McLaughlin M.J., Bundschuh, J. and Panaullah, G. 2007. Arsenic in the environment: biology and chemistry. Science of the Total Environment, 379(2-3): 109-120. https://doi.org/10.1016/j.scitotenv.2007.02.037

[5] Bundschuh, J., Garcia, M.E., Birke, P., Cumbal, L.H., Bhat tacharya, P. and Matschullat, J. 2009. Occurrence, health effects and remediation of arsenic in groundwaters of Latin America. In: Bhattacharya, J., A.B. Matschullat, M.A. Armientan et al. (Eds.), Natural Arsenic in Groundwaters of Lat in America. Taylor \& Francis, London, UK, pp. 3-15

[6] Bhattacharya, P., Hossain, M., Rahman S.N. et al. 2011. Temporal and seasonal variability of arsenic in drinking water wells in Matlab, southeastern Bangladesh: a preliminary evaluation on the basis of a 4 year study. Journal of Environmental Science and Health A: Toxic/Hazardous Substances and Environmental Engineering, 46(11): 1177-1184. https://doi.org/10.1080/10934529.2011.598768

[7] Ravenscroft, P., Brammer, H. and Richards, K. 2009. Arsenic Pollution: A Global Synthesis, John Wiley \& Sons, West Sussex, UK, 2009. https://doi.org/10.1002/9781444308785

[8] Ahmed, M.F. 2005. Arsenic mitigation technologies in south and east Asia. In: Towards a more effective operational response, vol. 2, Technical Report No. 31303, Water and Sanitation Program-South Asia and the World Bank, pp. 166-207.

[9] Shankar, S., Shanker, U and Shikha. 2014. Arsenic Contamination of Groundwater: A Review of Sources, Prevalence, Health Risks, and Strategies for Mitigation. The Scientific World Journal, 2014: 1-18 https://doi.org/10.1155/2014/304524

[10] Environment Conservation Rules, Schedule 3, 1997. Urban water supply coverage in Bangladesh is defined as one household per connection or one street hydrant per 100 people. The standards for the definition of safe drinking water in Bangladesh are comparable to those of most other countries.
[11] DANIDA (Danish Agency for International Development Aid). 2005. Water Supply and Sanitation Sector Programme Support (WSSPS) Phase II. Sector Policy Support Component, Bangladesh.

[12] Talukder, S.A., Chatterjee, A., Zheng, J. and Kosmus, W. 1998. Studies of drinking water quality and arsenic calamity in groundwater of Bangladesh. Proceedings of the International Conference on Arsenic Pollution of Groundwater in Bangladesh: Causes, Effects and Remedies, Dhaka, Bangladesh, February 1998.

[13] Khan, S.A., Mulvaney, R.L. and Mulvaney. C.S. 1997. Accelerate diffusion methods for inorganic-nitrogen analysis of soil extracts and water. Soil Science Society of America Journal, 61: 936-942. https://doi.org/10.2136/sssaj1997.03615995006100030032x

[14] Safiuddin, M. and Karim, M.M. 2001. Groundwater arsenic contamination in Bangladesh: causes, effects and remediation. Proceedings of the 1st IEB International Conference and 7th Annual Paper Meet, 2-3 November, 2001, Institution of Engineers, Chittagong, Bangladesh.

[15] Daily Star Report. 1999. An Urgent Call to Save a Nation. The Daily Star, a National Daily Newspaper of Bangladesh, 10 March 1999.

[16] Smith, A.H., Lingas, E.O. and Rahman, M. 2000. Contamination of drinking water by arsenic in Bangladesh: a public health emergency. Bulletin of World Health Organization, 78(8): 1093-1103.

[17] USEPA. 2001. National Primary Drinking Water Regulations: Arsenic and Clarifications to Compliance and New Source Contaminants Monitoring," Federal Register, vol. 40, CFR Parts 9, pp. 141-142, 2001.

[18] WHO. 2011. Guidelines for Drinking-Water Quality, vol. 4. World Health Organization (WHO).

[19] USEPA. 2013. Arsenic in Drinking Water http://water.epa.gov/lawsregs/rulesregs/sdwa/ arsenic/index.cfm.

[20] Santra, S.C., Samal, A.C., Bhattacharya, P., Banerjee, S., Biswas, A., and Majumdar, J. 2013. Arsenic in foodchain and community health risk: a study in gangetic west Bengal. Procedia Environmental Sciences, 18: 2-13. https://doi.org/10.1016/j.proenv.2013.04.002

[21] Rai, A., Tripathi, P. and Dwivedi, S. et al. 2011. Arsenic tolerances in rice (Oryza sativa) have a predominant role in transcriptional regulation of a set of genes including sulphur assimilation pathway and antioxidant system. Chemosphere, 82(7): 986-995. https://doi.org/10.1016/j.chemosphere.2010.10.070

[22] Brinkel, J., Khan, M.H. and Kraemer, A. 2009. A systematic review of arsenic exposure and its social and mental health effects with special reference to Bangladesh. International Journal of Environmental Research and Public Health, 6(5): 1609-1619. https://doi.org/10.3390/ijerph6051609

[23] Wegelin, M., Gechter, D., Hug, S., Mahmud, A. and Motaleb, A. 2000. SORAS-A Simple Arsenic Removal Process. phys4.harvard.edu/ wilson/mitigation/SORAS_Paper.html.

[24] Young, E. 1996. Cleaning Up Arsenic and Old Waste. New Scientist, 14 December 1996.

[25] BAMWSP-DFID-WaterAid (Bangladesh Arsenic Mitigation Water Supply Project, United Kingdom Department for International Development, WaterAid Bangladesh). 2001. Rapid Assessment of Household Level Arsenic Removal Technologies, Phase-I and Phase-II. Final Report. W. S. Atkins International Limited.

[26] Edwards, M. 1994. Chemistry of arsenic removal during coagulation and Fe-Mn oxidation. Journal of American Water Works Association, 86(9): 64-78.

[27] Ali, M.A., Badruzzaman, A.B.M., Jalil, M.A., Hossain, M.D., Hussainuzzaman, M.M., Badruzzaman, M., Mohammad, O.I. and Akhter, N. 2001. Development of low-cost technologies for removal of arsenic from groundwater. In: Ahmed, M.F., M.A. Ali, and Z. Adeel (Eds.), Technologies for Arsenic Removal from Drinking Water. Bangladesh University of Engineering and Technology and United Nations University, pp. 99-120. 
[28] Ahmed, M.F. 2003. Treatment of Arsenic Contaminated Water. In: Ahmed M.F. (Ed.), Arsenic Contamination: Bangladesh Perspective, Dhaka, Bangladesh, pp. 354-403.

[29] Ahmed, M.F. and Rahaman, M.M. 2000. Water supply and sanitation - low income urban communities. International Training Network Centre, Bangladesh University of Engineering and Technology.

[30] Dahi, E. and Liang, Q. 1998. Arsenic removal in hand pump connected iron removal plants in Noakhali, Bangladesh. Paper presented at the International Conference on Arsenic Pollution of Ground Water in Bangladesh: Causes, Effect and Remedies, Dhaka, 8-12 February, 1998.

[31] Joshi, A. and Chaudhuri, M. 1996. Removal of arsenic from groundwater by iron-oxide-coated sand. ASCE Journal of Environmental Engineering, 122(8): 769-771. https://doi.org/10.1061/(ASCE)0733-9372(1996)122:8(769)

[32] Shin Nihon Salt Co. Ltd. 2000. Report on Performance of Read-F Arsenic Removal Unit (ARU).

[33] Water Aid Bangladesh and DFID. 2006. Advancing Sustainable Environmental Health Bangladesh. Project Memorandum, Dhaka.

[34] DFID (Department for International Development) and UNDP (United Nations Development Programme). 2007. Urban Partnerships for Poverty Reduction. Project Memorandum, Dhaka.

[35] World Bank. 2007. Implementation Completion and Results Report (IDA-31240 SWTZ-21082) on a Credit in the Amount of SDR24.2 Million (US\$44.4 Million Equivalent) to Bangladesh for Arsenic Mitigation Water Supply, Washington, D.C 